Pregledni članak UDK: [575.8:574]:17.023.3(045)

doi: $\underline{10.21464 / \mathrm{fi} 41209}$

Primljeno 10. 10. 2019.

\author{
Saša Marinović \\ Rudolfa Bićanića 22, HR-10000 Zagreb \\ sasa.marinovic@gmail.com
}

\title{
Teleologija i evolucija - Aristotel i Hans Jonas u kontekstu ekološke etike
}

\begin{abstract}
Sažetak
Aristotel je istraživanja pomoću empirijske metode interpretirao obimno se koristeći metafizičkim konceptima. Neki autori smatraju da je njegova metafizički intonirana filozofija biologije spojiva s modernom teorijom evolucije te s nekim od bitnih tema ekološke etike. Pokušat ćemo pokazati kako je tumačenje supstancijalne cjeline, pod vidom pojma potencijalnosti, Aristotelov doprinos raspravama ekoetičkog holizma. Nadalje, prikazat ćemo kako Hans Jonas pronalazi i mogućnost vrednovanja individualne organske supstancije u Aristotelovim djelima, a koje nisu samo predstavnici ljudske vrste. Hans Jonas pledira za reviziju moderne teorije evolucije koja bi, združena s nekim Aristotelovim metafizičkim elementima, mogla izbjeći redukcionizam kojemu je bila izložena nakon Descartesa.
\end{abstract}

Ključne riječi

Aristotel, evolucija, supstancijalna cjelina, Hans Jonas, etika odgovornosti, ekološka etika

\section{Aristotelova znanstvena metodologija}

Teško je s odmakom od 2500 godina razmatrati Aristotelov rad u svjetlu moderne biologije i teorije evolucije. Tim više, ako se evolucijsku teoriju povezuje s Aristotelovim obimnim radom koji je, po nekim autorima, kontinuirani pokušaj realizacije filozofije prirode. Određene su proto-evolucijske teze, smatraju Škorić i Kišjuhas, bile iznošene od strane istraživača prije Aristotela. Tales, kojega Aristotel smatra osnivačem istraživanja fizičkog svijeta (Škorić i Kišjuhas, 2012, str. 17), započeo je s programom istraživanja prirode kakav nije više podrazumijevao 'transcendentne faktore' uređene stvarnosti, nego zakone univerzuma - prirodne zakone - razvijajuće danosti. Nadalje, može se reći da je Anaksimandar zastupao inačicu teze o heterogenezi, što Aristotel preuzima, ali i abiogeneze, što se smatra njegovom središnjom idejom kada je riječ o biološkim istraživanjima, čime ga se drži proto-evolucionistom (Škorić i Kišjuhas, 2012, str. 17-29). Za Empedokla se smatra, prenose Škorić i Kišjuhas, da je prvi jasno izrazio ideju prirodne selekcije, a prve konture adaptacije u biološkom razvoju naznačili su Anaksagora i Demokrit (Škorić i Kišjuhas, 2012, str. 21).

Aristotelova istraživanja sublunarnog svijeta pomoću empirijskih metoda dugo su ostala skrivena, ignorirana i, posljedično, malo studirana (Barbarić, 1995, str. 231). Kada se u obzir uzmu diskutabilni opisi ponašanja nekih živih bića koje je Aristotel zabilježio u svom najznačajnijem zoološkom djelu Historia animalium, ${ }^{1}$ poput onog da bizon izmet baca osam metara ili da samo

Barnes smatra da grčka riječ historia znači ispitivanje ili istraživanje te bi umjesto prijevoda historija trebalo stajati istraživanje. Time bi i prijevod djela Historia animalium

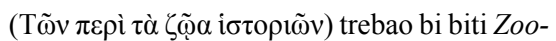
loška istraživanja umjesto Historija životinja (Barnes, 1996, str. 22). 
ljudi imaju otkucaje srca (O'Rourke, 2004, str. 6), tada se može razumjeti svojevrstan odium spram Aristotelovih prirodnih tekstova. Opisi poput gore spomenutog mogu se pripisati nedostatku tehničkih instrumenata i pogreškama u prosudbi (Barnes, 1996, str. 26), međutim, obimnost, složenost i preciznost razlozi su zbog kojih se ne može eliminirati relevantnost empirijske građe koju nam je Aristotel ostavio u naslijeđe.

Istraživanja na području bioloških fenomena Aristotel započinje djelom

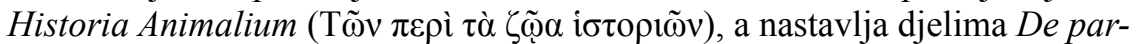

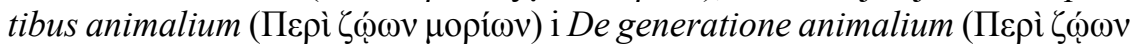
$\gamma \varepsilon v \varepsilon ́ \sigma \varepsilon(\varsigma)$. Prvo spomenuto djelo predstavlja faktičku građu istraživanja, dok su kauzalna objašnjenja iznesena u zadnja dva dijela (Lennox, 2017, str. 6). Kauzalna objašnjenja temelje se na djelima Prva i Druga analitika, koja čine kategorijalnu referencu za znanstveno shvaćanje i teorijsko organiziranje svakodnevnog iskustva, što Aristotela stavlja na sam početak metodologijski rafiniranog pristupa znanstvenom istraživanju prirode. Pored toga, Aristotel pokušava putem specijalističkog načina istraživanja, dakle, istraživanja »na terenu«, doseći generalističku, odnosno holističku razinu povezanosti svijeta života (Boylan, 2017, str. 4). U takvom programu istraživanja Aristotel četiri temeljna uzroka za biološka istraživanja svodi na dva: materijalni (materijalni i eficijentni) i teleologijski (finalni i formalni) (Boylan, 2017, str. 5-8), gdje formalni uzrok, pored holističkog objašnjenja prirode, predstavljaju važnu temu za ovaj rad.

Osim što je metodologijsko-logički oblikovana, Aristotelova biologija je, po tvrdnjama Franka O'Rourkea (2004), impregnirana konceptima njegove metafizike i bez nje je neshvatljiva. Budući da filozofija znanosti istražuje i koncipira teoriju kroz dvije temeljne dimenzije, metafizičku i empirijsku, kao dvije strane jedne stvarnost, tako i moderna biologija, prema O'Rourkeu (2004), ima potencijal biti tumačena kroz Aristotelov pojam forme, ali i drugih koncepata njegove metafizike.

\section{Metafizička osnova Aristotelovih biologijskih istraživanja}

Opisom razvoja embrija kod živih bića, kojim oponira Demokritovoj teoriji preformacije, Aristotel nagovještava nešto što će gotovo biti kanon moderne biologije, a to je epigeneza. Pored toga, hereditet kod Aristotela tumačen je kao prisutan u svim dijelovima stanice (Kullmann prema O'Rourke, 2004, str. 10), što je teza do koje je tek u 17. st. došao William Harvey, osnivač moderne biologije. Dakle, osobiti istraživački duh i iznimna sintetička sposobnost teorijskog zahvata omogućili su Aristotelu postavljanje teza koje su bile nenadmašne sve do 19. st. (Mayr, 1998, str. 155).

Sve stvari koje jesu, koje egzistiraju, odnosno imaju narav (physis) moraju biti sastavljene od materije i forme (Metafizika 1015a5), teorijska pozicija koja se nakon Aristotela putem tumača uvriježila pod nazivom hilemorfizam. Ujedno, narav je i prvotna tvar i oblik i bivstvo koje je svrha postanka. Bivstvo time postaje odrednica prirodnih stvari koje u sebi samima imaju počelo kretanja, dakle, imaju atribute stvaranja i rasta. Aristotel smatra da svako znanstveno istraživanje prirodnih fenomena i događaja mora biti objašnjeno putem četiri nužna čimbenika ili uzroka: materijalnog, formalnog, eficijentnog i finalnog (Metafizika 1044a33-1044b1). Formu (eidos) Aristotel u Fizici naziva uzorom ili modelom (Guthrie, 2007, str. 213) i shvaća je s natruhama transcendentnog značenja koje bi ona imala i kod Platona, samo u nešto eksplicitnijem 
obliku. Dakle, forma ima značenje izvanjskog uzora i unutarnje forme (Guthrie, 2007, str. 213), ona determinira postojanje svari, a stvari su određene svojim esencijalnim i univerzalnim svojstvima (Anders i Lie, 2016, str. 46). U samoj je stvari esencijalno ono nužno, bez čega same stvari ne bi moglo biti i to je mjesto kod Aristotela koje ga 'razotkriva' kao esencijalista (Anders i Lie, 2016) jer stolac nema esencijalnu karakteristiku kretanja iz samog sebe, dok ga prirodna i živa stvar posjeduje i to joj je određujuća karakteristika (Fizika 199b26-30).

Ono što Aristotelove postavke razlikuje od Platonova esencijalizma jest nemogućnost pristajanja uz ideju svijeta koji je neovisan od svijeta osjetilnog iskustva. Iako je ostao vjeran postavci kako iza svega što se mijenja mora biti nešto nepromjenjivo, nekakva forma, smatrao je da bitna odrednica svakog predmeta, njegov eidos, mora biti u njemu samome, združen i nerazdvojiv od materijalne komponente. Tako će pojedinačno biće ili predmet biti jedino stvarno polazište istraživanja, odnosno, jedina prava supstancija koju, da bismo je spoznali u njenim počelima (arhai) i uzrocima (aitia), moramo rasvijetliti u određenjima kao što su klase pripadanja ili njene logičke strukture (Guthrie, 2007, str. 95). To je već jedan vid esencijalizma prije esencijalizma jer se, da bi istraživanje bilo pravilno, prvo bića moraju postaviti u neke klase, a koje su određene nekim drugim, za Aristotela, prilično važnim faktorima, kao što su forma (eidos) i svrha (telos). Taj esencijalizam prije esencijalizma kod Aristotela znači zapravo hipotezu, smatra Guthrie (2007, str. 102-103), iz čega proizlazi da se teleologija može, ali i ne mora, dokazati kao najvažniji među četiri uzroka.

Prvo što ćemo tematizirati, osobito u kontekstu ekološke etike, jest pitanje holizma kod Aristotela. Na jednom mjestu Aristotel piše:

»U svih stvari koje imaju više dijelova i kojima ukupnost nije kao neka hrpa, nego im je cjelina štogod mimo dijelova, postoji nekakav uzrok.« (Metafizika 1045a10)

Na drugom mjestu kaže:

»Sve su stvari sređene nekako, ali ne istim načinom, i ribe i ptice i biljke; a ništa se ne ponaša tako kao da nema nikakva odnošaja jedno prema drugome, nego jest nekakav odnošaj. Jer sve se stvari sređuju prema jednom [...].« (Metafizika 1075a10-15)

Aristotela zanima što to čini da nešto mnogovrsno postoji kao jedno; zanima ga koji je uzrok ujedinjenju. Scaltsas (1994) smatra kako su supstancije najjedinstvenije cjeline (most unified wholes), a opet vrlo složeni entiteti, gdje se složenost shvaća u odnosu na supstancijalnu formu (Scaltsas, 1994, str. 108). Rezultirajuća cjelina nije ovisna o međusobnim odnosima njenih komponenti, nego o identitetu sa supstancijalnom cjelinom. Supstancijalna cjelina za Scaltsasa predstavlja metafizički termin čije su rangiranje i kriteriji opisani u Metafizici (1052a15-20), dok se razlika koju Aristotel pravi između cjeline i pojedinačnih entiteta iznosi na drugom mjestu istog djela (Metafizika 1041b20-30). Ondje Aristotel iznosi zaključak kako je cjelina više od skupa njenih dijelova. Stoga, Scaltsas razlikuje ujedinjavanje koje je slučajno (incidental), temeljeno na konvenciji, od ujedinjavanja koje je supstancijalno. Supstancijalna cjelina mora biti iznad totaliteta njenih dijelova na način principa, a ne skupa elemenata; cjelina postaje uzrokom neke stvari (Metafizika 1041b27-31). Moramo naglasiti da, kada govorimo o supstancijalnoj cjelini, onda govorimo o drugačijem ontološkom statusu između entiteta koji čine određenu cjelinu i same cjeline. 
Aristotelov holizam možemo povezati s evolucijom u već ranije spomenutoj agendi sinoptičkog predstavljanja prirodnih fenomena. Jednako tako, kada govorimo o ekologiji, možemo reći da Aristotel, prije nego što govori o ekološkim fenomenima, ako takvi postoje, već ima koncept što ekologija jest (Anders i Lie, 2016, str. 47), a to je već spomenuta klasifikacija kod Aristotela.

Drugo mjesto koje u Aristotelovoj biologiji zaokuplja pažnju mnogih kritičara, a među njima i ekoetičara, je pitanje vrsta. Darvinizam, za razliku od Aristotelova gledišta, ne poznaje razlike između akcidentalne i supstancijalne promjene. Ernst Mayr smatra da kod esencijalista, među koje on uvrštava i Aristotela, vrste ne podliježu modifikacijama, dakle, adaptaciji i selekciji; vrste su, vodeći se načelom forme, nepromjenjive i fiksne (Mayr, 2000, str. 54-57). Alasdair MacIntyre smatra drugačije. Premda se može govoriti o tome kako forma mora sadržavati fiksnost da bi se reproducirala, kod evolucije, točnije darvinizma, možemo govoriti o akcidentalnoj promjeni koja dovodi do alteriranja tijeka formalne linearnosti. Jednostavno, svako individualno biće može biti podvrgnuto akcidentalnoj modifikaciji koja će njegovo potomstvo činiti drugačijim (O'Rourke, 2004, str. 26). Pitanje koje nam se postavlja, smatra O'Rourke, jest možemo li raditi takvu teorijsku adaptaciju, kada imamo na umu razliku između Aristotelovih koncepata supstancijalne i akcidentalne promjene (O'Rourke, 2004, str. 27). Dakle, po Aristotelovu mišljenju, svako biće ima nepromjenjivu osnovu, što u konačnici i jest razlog zašto Aristotela svrstavaju među esencijaliste u literaturi vezanoj za filozofiju prirode. Upravo esencijalizam predstavlja problem znanstvenom objašnjenju. Po Aristotelovu mišljenju, esencija predstavlja ontološki identitet određene individue i kao takvu je jedino supstancijalna promjena može alterirati. Ili možemo, kako je to pokušao MacIntyre, evoluciju shvatiti kao seriju akcidentalnih promjena, onih koje se tiču više materijalnog i eficijentnog, a manje formalnog i finalnog uzroka.

U tom smislu, Aristotel ne prihvaća da jedan oblik života nastaje iz drugog s obzirom na to da "pojedinačno nije nekakvo nešto zato što je kao nekakvo postalo - to važi za sva uređena i određena djela Prirode - već prije ono postaje takvo zato što mu je biće to einai takvo i takvo: postajanje prati bivstvo i jest radi bivstva, a ne prati bivstvo postojanje« (De generationis animalium 778b). Riječ je o životu koji uvijek ima samo jedan materijalni oblik, supstancijalan u smislu da iz njega ne može posredstvom iste forme proizaći drugi materijalni oblik. Odnosno, u najmanju ruku, Aristotel ne može objasniti kako nastaje promjena živog oblika u drugi živi oblik, znači, ne može objasniti promjenu, a time bi i Aristotelov nauk mogao biti podvrgnut istoj primjedbi o kretanju kakvu je on sam primijenio na elejsku školu (Škorić i Kišjuhas, 2011).

Ipak, neki su autori, primjerice David Balme, oponirali stavu da je Aristotelov nauk o prirodi esencijalistički. Konkretno Balme smatra kako su pojmovi vrsta (species), bit (essentia) i supstancija (substantia) neo-platoničko srednjovjekovno interpretiranje Aristotela (Balme, 1980, prema O'Rourke, 2004, str. 38). Tu je posrijedi miješanje logičkog i naturalnog, gdje se esenciju želi nametnuti kao nepromjenjivu kategoriju živog i razvijajućeg. Pretpostavljamo kako je zbog obimnosti istraživačkog interesa, ali i zahtjevnosti bilježenja empirijskih rezultata, došlo do međusobno isključivih formulacija. Aristotel na mnogim mjestima daje do znanja kako forma nije toliko monolitan pojam. Recimo, kako smo već istaknuli, u Metafizici (1075a) piše da su sve stvari (»i ribe i ptice i biljke«) u odnosu jedne prema drugima i sređene vodeći se prema 
nekakvom jednom, što je formulacija koja se može prilično lako povezati s generalnim stavom evolucijske teorije kao panoramskog opisa života (O'Rourke, 2004: 38). Nešto eksplicitnije tumačenje forme kao ne toliko fiksne kategorije Aristotel iznosi u De partibus animalium, gdje piše sljedeće:

»Priroda prelazi bez prekida od onog što nema dušu k životinjama kroz ono što je doduše živo ali nije životinja [...].«(De partibus animalium 681a12-15)

Preklapanje rodova ističe u De generatione animalium (732b15-20). Ipak, i jedno i drugo mjesto tiče se odnosa toplokrvnih i hladnokrvnih životinja kao odnosa savršenijeg i manje savršenog oblika života. Ovdje Aristotel govori o vertikali vrijednosti određenog oblika života, gdje su toplokrvne životinje savršenije od onih životinja koje nisu tople krvi. Na individualnoj razini imamo savršenije oblike života, a na globalnoj razini imamo savršenije stanje prirode kao totaliteta. Budući da Aristotel prirodi pripisuje inherentnu teleološku aktivnost, kretanje kao promjena ima svoje stupnjeve koji mogu biti kvantitativne i kvalitativne naravi, a sve u okviru tzv. scalae naturae.

Suvremeno promatranje evolucijske biologije, za razliku od vremena kada je biologiju istraživao Aristotel, teleološki princip uzima kao vitalističko objašnjenje prirodnih procesa. Vitalizam je, kako ga tematizira Jacques Monod, jedna od mističnih točaka u kompleksima znanja, odnosno, trenutak neznanja. Time se vitalizam predstavlja kao svojevrsno praznovjerje i otpor prema znanstvenom znanju (Mono [Monod], 1983, str. 51-70). Monod ide tako daleko da tvrdi kako je vitalizam junačka borba čovjeka da dokaže sebi kako je vječan, odnosno, da potvrdi sebi kako nije kontingentan. Pravo znanje bilo bi, po Monodovu mišljenju, savršena zrcalna slika vanjskog svijeta, no vitalizam je slika saturirana subjektivnim sadržajima koji se predstavljaju kao potpuno predvidivo, nužno i nepromjenjivo stanje stvari. U narednim poglavljima razmotrit će se vitalizam u kontekstu Jonasove filozofije, odnosno može li se u sklopu, uvjetno govoreći, trodiobe njegove filozofije (Brune, 2003) pronaći smisao vitalističkog tumačenja filozofije.

\section{Aristotel kao ekocentrist}

Budući da svaka spoznaja za Aristotela mora krenuti od konkretne, materijalne stvarnosti da bi rezultirala u ideji kao zaokruženom rezultatu misaonog i znanstvenog angažmana, tako i pitanje ekologije, mogli bismo reći, mora biti zaokružena tema $i$ to do te mjere da ekosustav smatramo entitetom ili, Aristotelovim rječnikom, supstancijom. Iz takvog kuta gledanja, u kontekstu ekoetike, Aristotela možemo promatrati kao ekoetičkog holista ili ekocentričkog autora. Aldo Leopold, jedan o pionira artikuliranog predstavljanja ekocentričke teorije, svoju je poziciju definirao ovako:

»Stvari su ispravne kada teže očuvanju integriteta, stabilnosti i ljepote biotičke zajednice. Pogrešne su ako teže suprotnome.« (Leopold, 1966, str. 282)

Dakle, težnja prema očuvanju cjeline primarna je jednako za Aristotela kao i za Alda Leopolda. Za Aristotela je primarnost metafizičke naravi, a za Alda Leopolda etičke, što nas može navesti na zaključak kako je, barem u potenciji, Aristotel ekocentrički etičar.

U kontekstu ekoetičkog holizma ostaje pitanje jesu li cjeline samo puka ujedinjavanja ili su nešto više od toga. Kako smo već navodili, kod Aristotela postoje supstancijalna i konvencionalna razina ujedinjenosti (agregati i relativne 
cjeline). Ako je riječ samo o konvencionalnoj razini, onda ujedinjenost doista ne daje dovoljno razloga da bismo ga etički opravdali, dok je kod supstancijalne ujedinjenosti riječ o nečemu sasvim drugačijem. Vrste ili ekosustavi jesu, gledajući taksativno, samo skupovi jedan pored drugog i mi možemo, ovisno o značajkama svake od njih i njihovoj unutarnjoj povezanosti, znati što ih čini osobitima. Ono što ostaje problem jest, jesu li vrste ili ekosustavi kao cjeline nekakve supstancije te mogu li kao takve biti nosioci moralne vrijednosti. Prelazimo ovdje na Aristotelovo objašnjenje supstancijalne cjeline. Što je to što čini cjelinu supstancijalnom, a pritom konstitutivne elemente zadržava kao supstancijalne individualne entitete?

Aristotel je odgovor pronašao u pojmu potencijalnosti kao nečeg što jest, a nije konkretno sada prisutno (Scaltsas, 1994, str. 128). Individualni supstancijalni entiteti i holistički supstancijalni entitet dijele konstitutivni element, a to je potencijalnost. Čovjek/životinja, vrsta i ekosustav jesu supstancije s različitim modusom bivanja čija se istost (sameness) ogleda u konstitutivnom elementu potencijalnosti (Scaltsas, 1994, str. 120). Cjelina nije supstancijalna $\mathrm{u}$ tom što je posrijedi potpuno integriranje njenih elemenata u nešto nadindividualno, nego u tome što pojedini entiteti, kao totaliteti, čine cjelinu u smislu mogućnosti. Na tragu Aristotela (Metafizika 1035b15-25), Scaltsas je to izrazio na sljedeći način:

»Komponente supstancije samo su potencijalno entiteti koji mogu postojati neovisno od cjeline i obrnuto, entiteti koji postoje neovisno od cjeline samo su potencijalno supstancijalna cjelina.« (Scaltsas, 1994, str. 121)

Po Scaltsasovu mišljenju, Aristotela je potrebno shvaćati na taj način da on spoj materije i forme u određenoj supstanciji ne želi tumačiti kao dva sukladna principa unutar određenog entiteta. Naime, ja kao individualna cjelina svoje postojanje dugujem supstancijalnoj formi putem identiteta, međutim, supstancijalna forma duguje svoje postojanje meni putem egzistencijaliteta. Ono što jesam in concreto omogućuje mi da spoznam in abstracto uzroke (aitia) svoga postojanja, koji su nešto opće, time ujedno shvaćajući svoj telos. Jedno je važno - svaka podjela supstancije na konstitutivne dijelove rezultat je apstrakcije ili fizičke intervencije; dijelovi nisu elementi unutar supstancije koji funkcioniraju zasebno, nego se granica njihovog bivanja zamaglila (Scaltsas, 1994, str. 122). Kada ovdje dijelimo ekosustav na materiju i formu, to činimo na apstraktan način, na način da su konstituenti apstraktni entiteti, u smislu da ne mogu postojati neovisno o svom konstitutivnom parnjaku.

Kako možemo uslijed ovakvog pogleda na cjeline shvatiti ekosustav kao supstancijalni entitet? Promotrimo li Aristotelove argumente, nameće nam se pitanje moralnog značaja konkretnih pojedinačnih entiteta. Gubi li se u Aristotelovu shvaćanju individualno živo biće? Po Scaltsasovu mišljenju ne jer Aristotel razlikuje identitetsku ovisnost unutar cjeline nasuprot relativne povezanosti i pukog agregata. Kada se agregat razbije, njegovi dijelovi mogu i dalje pojedinačno funkcionirati jer je povezanost relativna, međutim, kada se supstancijalna cjelina razbije, tada se i sama supstancija negira. Supstancijalna cjelina mišljena je u apstraktnom smislu (Metafizika 1041a25-30) i ne može se fizički podijeliti jer su granice između njenih komponenti gotovo pa iščezle. Time se ponovno vraćamo na zaključak kako su supstancije samo potencijalno entiteti koji mogu postojati neovisno od cjeline i obrnuto, a entiteti koji postoje neovisno od cjeline samo su potencijalno supstancijalna cjelina. Znači, pojedinačni entiteti poput ljudi, životinja ili biljaka jednom kada postanu dio cjeline - pogotovo dio cjeline biološkog života - mijenjaju identitet 
»neovisnih o cjelini«, ovisno o tome koja je njihova uloga u danoj supstancijalnoj cjelini; one postaju jedno, ali u potencijalnom smislu.

Jednako tako i vrstu možemo shvaćati kao supstancijalnu cjelinu. Vrsta se može shvaćati kao forma koja svoj materijalni pandan ima u svim jedinkama koje predstavlja. Tako će određena jedinka neke vrste biti nerazdruživi dio vrste kao cjeline u tome što reprezentira sva svojstva koja vrsta formalno posjeduje. Sama individua u takvom kontekstu ne gubi ni na važnosti ni na moralnoj vrijednosti, njena težnja da egzercira karakteristike cjeline čini je nerazdruživim elementom iste te cjeline, a čini je i supstancijom, što nosi određenu moralnu konsekvencu. Individua aktualno jest pojedinačna supstancija, međutim, težnjom da zadrži sve karakteristike njene vrste, ona je i pripadnica supstancijalne cjeline. U takvom odnosu i individua i cjelina mogu se shvaćati kao nosioci moralne vrijednosti. Individua se shvaća kao konkretna moralna instanca koju se etički situira ovisno o njenim supstancijalnim karakteristikama, dok se vrsta ili ekosustav shvaćaju kao ono »treba biti« pojedinog entiteta; apstraktnu suštinu bez koje ne bi moglo biti shvaćanja samog individualiteta (ljudskog, životinjskog ili biljnog) u svom njegovom bogatstvu.

Vraćamo se na definiciju cjeline Alda Leopolda. Stabilnost cjeline kao osnova moralnog postupanja stanoviti je moralni redukcionizam (Marietta, 1998, str. 458). Aldo Leopold polazi od toga kako svaka individua u ekosustavu obavlja svoju funkciju i dok je god obavljanje te funkcije u skladu s načelima cjeline (spomenuta definicija holizma), dotad je vrijednost određene individue neporeciva. Svo bogatstvo određene individue ostaje zanemareno poradi stabilnosti cjeline, što Leopoldovu poziciju čini redukcionističkom. Odnosno, svaki oblik ekstremnog holizma (prema: Marietta, 1998) čini redukcionističku pogrešku jer individuu predstavlja isključivo kao element cjeline, bez dubljeg pojedinačnog značaja, dok je pozicija koja se može iščitati iz Aristotelovih eksplikacija, ako ništa drugo, onda ublažena varijanta holizma.

Aristotela nikako ne možemo proglasiti holistom par excellence, pogotovo ne u ekoetičkom smislu jer, kako smo već naglasili, sve kreće od pojedine i konkretne supstancije. One su određene formom i svrhom te se njihova eudaimonia jasno ocrtava. Svaka jedinka posjeduje mogućnosti koje trebaju biti realizirane da bismo mogli govoriti o životu vrijednom življenja. Martha Nussbaum (2006, str. 392-401) nabraja niz sposobnosti koje posjeduju ne samo ljudi nego i životinje, a koje su esencijalne da bi individua mogla realizirati ispunjen i za svoju vrstu dostojanstven život. Ostaje pitanje kako u sklopu Aristotelove filozofije biologije, a ne zanemarujući teoriju evolucije, shvaćati život i vrijednost jedinke. Na to će nam pitanje u daljnjem tekstu, nadamo se, odgovoriti Hans Jonas.

\section{Fenomen života Hansa Jonasa}

Filozofija života za Hansa Jonasa obuhvaća filozofiju živih bića i filozofiju uma. To znači da pretpostavlja kako organsko na svojim najnižim razinama posjeduje um, ali i to da um na svojim najvišim razinama sadržava organsko. Bez obzira na mehanicističko viđenje života, Jonas smatra, ekspli-

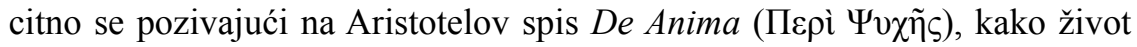
predstavlja uzlazeći fenomen u koji su smješteni sofisticirana forma, nagon osjeta i poticaj želje, komanda udova i sposobnost djelovanja, refleksivnost svijesti i težnja za istinom. Stoga Jonas i piše kako je Aristotel spomenutim spisom prvi govorio o filozofiji biologije. Njegove stavove Jonas u potpunosti 
ne prihvaća, ali činjenice poput stratifikacije, progresivne superpozicije razina s međuovisnošću viših s nižima i zadržavanjem nižih u višima, nešto je nezaobilazno u filozofiji biologije, čak i danas. Aristotelovu scala naturae možemo, po Jonasovu mišljenju, tumačiti na dva načina. Jedan je način taj da odredimo obim i razliku iskustava rastuće sposobnosti percepcije svijeta koji se kreće prema sve širim i slobodnijim objektifikacijama sume bića u individualnom percipijentu. Drugi se način, konkurentan s nijansama percepcije, oslanja na činjenicu progresivnog rasta slobode djelovanja ili slobode da se djeluje. Međudjelovanje spoznaje i postupanja, djelovanja, akta, činidbe itd. predstavlja stalnu temu proučavanja formi života.

Jonas u evoluciji pretpostavlja mogućnost materijalističkog shvaćanja čovjeka postavljenog u kontinuum života, nastojeći biološkom aspektu dati ontološku važnost. Takvim postupkom Jonas otvara mogućnost da u jednom »formalnom« oplemenjivanju materije, a time i biološke stvarnosti, vrijednost po istoj osnovi pronađe kako u čovjeku, tako i u prirodnom svijetu (Morris, 2013, str. 51). U proučavanju evolucijske biologije, smatra Theresa Morris, Jonas pokušava pomiriti materijalističko shvaćanje prirode $\mathrm{s}$ novim vidom shvaćanja života u njegovoj raskošnosti i mogućnosti. Poglavito će se ti aspekti života nazrijeti u dinamizmu živoga i međuovisnosti njegovih oblika.

Jonas je, prije svega, okrenut kritici filozofije renesanse i humanizma, odnosno mehanicističkog tumačenja prirode u periodu moderne. Osobito se osvrće na sedamnaesto stoljeće kada se, u potrebi da se sve doživi kao mehanizam i da se istraži njegovo funkcioniranje, nije postavljalo pitanje o uzrocima i počelima, dakle o aitia i arhe, kako je to već postavljao Aristotel. To je, po Jonasovu mišljenju, otvorilo put u deizam osamnaestog stoljeća, koji je stvoritelja predstavio kao konstruktora. Jednom stvoren svijet od strane Velikog konstruktora, dalje nastavlja sam svoje procese vođen fizikalnim zakonima. U takvom, kaže Jonas, novom pristupu, važnost imaju samo procesi uzroka i posljedice unutar fizičkoga svijeta. Bog je svoju intervenciju obavio na početku stvaranja, a dalje sve ostaje podložno kauzalitetu.

Otpor takvom tumačenju porijekla dugo se taborio u pitanjima živoga svijeta, ali je i on pokleknuo kada je u devetnaestom stoljeću na scenu stupila teorija evolucije. Jonas (1966) problem vidi u opterećenosti prirodnih istraživanja Descartesovom ostavštinom u kojoj se priroda i životinje razumiju kao puki bez-životni i bez-dušni mehanizmi i kao takvi bez inteligencije i svrsishodnosti za razliku o čovjeka, koji stoji u ekskluzivnom odnosu spram boga. Evolucija je, po Jonasovu mišljenju, omogućila inauguraciju teme prirodnoga svijeta u koncept svrsishodnog razvoja, polako je izopćujući iz mehanicističkog okvira materijalno-kauzalističkog modela eksplanatornosti.

No evolucija je, barem u njenom modernom smislu, odbacila značenje koje je imala u klasičnom smislu, a to je razvoj pojedinačnog organizma. Shvaća li se kao proces koji se odvija bez plana - neusmjeren, ali ipak razvijajući proces - prirodu se lišava svake forme teleološkog gibanja. Do trenutka probitka evolucije dovoljno je bilo opisati funkciju mehanizma nekog živog bića i time bismo rekli sve o životu neke jedinke. Nakon što se evolucija probila u teoriju, život se počeo shvaćati kao nešto iz čega se funkcija neminovno javlja, a ta je funkcija preživljavanje sustava. To nadalje prati, smatra Jonas, pobjedu nominalizma nad realizmom jer evolucija razbija polazište o nepromjenjivosti vrste, čime se evolucija snažno suprotstavila esencijalizmu platonizma i aristotelizma. Uvjeti (conditions), smatra Jonas, postaju esencija bića, tako će uvjeti bića u obliku okoliša (environment) postati princip determinacije 
organizma. Život se, dakle, shvaća kao odnos organizam - okoliš, a ne kao ostvarenje autonomne prirode (Jonas, 1966, str. 45-48). To će u konačnici dovesti do dva bitna procesa, a to su nužnost i kontingencija. Prvo je izraz mehanicističke znanosti, a drugo izraz materijalističkog monizma, odnosno naturalističkih teorijskih postavki u koje se uklapa evolucija.

Pod vidom nužnosti i kontingencije, Jonas organizam shvaća kao podvrgnut dvama procesima: mutaciji i interakciji s okolišem. Mutacija je proces koji se odvija unutar jedinke, a prirodna selekcija je izvanjski proces koji se odvija u interakciji jedinke s okolišem. Znači, ništa nije stabilno u neprestanoj igri bića i ne-bića, kaže Jonas (1966, str. 48-53). Mehanizam selekcije time preuzima mjesto teleologiji te se upravlja prema određenom »napretku « putem negativne teleologije. Emergencija forme ostvaruje se igrom slučajnosti odstupanja od zadanog puta i usmjeravanja uvjetovanog stranim i izvanjskim faktorima. U takvim okolnostima napredak se može tumačiti kao niz nesreća, a uspon kao čista slučajnost, što Jonasa navodi na pitanje: možemo li pod ovim vidom okolnosti objasniti složeni i izvanredno prilagođeni oblik života?

Pomalo sofistički, Jonas će ustvrditi kako je usložnjavanje organizma zapravo jedan patološki proces. Ako je gen određena stabilnost i prijenos nasljednosti, on je tada određena vrlina. Pod određenim vanjskim utjecajima, mutacija je $u$ tom pogledu smetnja koja probija stabilnost sustava i mehanički vid degeneracije. Time će mutacija kao mehanički faktor preoblikovanja sustava zapravo predstavljati ometajuću pojavu u realizaciji »idealnog « puta zacrtanog u genu te će evolutivni proces predstavljati neprestanu deformaciju. Tako su jednostavni organizmi, koji su dosegli stupanj iznimne složenosti poput amebe, zapravo gigantske monstruoznosti, smatra Jonas.

Primjenjujući odnos organizam - okoliš na odnos organizam (soma) - klica (sjemena plazma), u jednom novom viđenju darvinizma, vezanom za gensku selekciju, dobivamo, kaže Jonas, novi dualizam. On se ogleda u tome da je sjeme nepromjenjiv, začetni plan koji se ostvaruje na promjenjivom tijelu organizma koje prolazi kroz životnu dramu. U tom shvaćanju Jonas pretpostavlja da bi se sjeme moglo tumačiti kao zamijenjeni ili čak i revitalizirani esencijalizam besmrtnosti vrste kojega nalazimo kod Platona i Aristotela. Takvo shvaćanje genskog nasljeđivanja u modernom znanstvenom tumačenju darvinizma zoran je dokaz koliko Jonas strahuje o sudbini tjelesnog lika biološkog života. Bojazan da će tjelesni oblici biti tumačeni kao efemerne pojave, jedan je od, možemo pretpostaviti, snažnih razloga za optiranje etike odgovornosti. Dakle, Jonas će u svojim nastojanjima da naglasi Aristotelova fizikalna istraživanja nastaviti putem svog omraženog profesora Heideggera. Također će biti značajno kritički raspoložen prema Descartesovu mehanicizmu te će pledirati za jedan novi okvir tumačenja prirode koji će afirmaciju tražiti u post-dualističkoj koncepciji života (Morris, 2013, str. 49). Stoga je za Jonasa Aristotelova koncepcija physisa važna zato što predstavlja harmonizacijsku točku dvaju vidova pojavnosti - uma i tvari. Physis kao forma, odnosno, kao život, medijacijska je točka između rex extensa i rex cogitans, čime Jonas jasno oponira Descartesu, pa i paradigmi suvremene znanosti.

$\mathrm{S}$ druge strane, Jonas u rigidno shvaćenom evolucionizmu vidi i opasnosti monizma koji će život opisati kao nužnost i slučajnost. U tom smislu život je samo izraz neprestanih procesa selekcije i mutacije, odnosno nužnosti i kontingencije. Kao takav, nikada nije uperen na neki viši smisao od onog pukog preživljavanja. Evolucija, dakle, pruža sasvim plauzibilno objašnjenje, sve dok se ne postavi pitanje počela (Morris, 2013, str. 54). No, iako sama 
ne može odgovoriti na pitanja počela, otvara, smatra Morris interpretirajući Jonasa, mogućnost za revalorizaciju života (Morris, 2013, str. 55).

Evolucijska je teorija učinila to da se kartezijanizam pokušao suspregnuti dajući kroz jedan opći, mehanicistički opis biološkog života naznake kako život sam po sebi ipak sadržava klicu digniteta. Evolucija, kod Jonasa filozofijski tumačena, pokazuje kako se um (psyche) gradualno javlja kroz evoluciju organskog života, što znači da čovjek nije odvojen od biološkog života uopće pa tako i od svog posebno (Jonas, 1966, str. 57). Time je za Jonasa putem filozofskog istraživanja evolucije otvoren prostor redefiniranju i revalorizaciji subjekta.

\section{Hans Jonas kao biocentrički individualist}

Aristotel je analogno čovjekovu umijeću (technê), kao svrsishodnom procesu, zaključio kako svaki proces nužno mora biti in-formiran telosom. Problem takvog tumačenja javlja se uspostavom i dugotrajnošću dekartovske ostavštine. Jonas smatra kako dualizam ima svoju tradiciju u određenom obliku i u antici (Jonas, 1966, str. 7-37), ali u renesansnoj koncepciji svijeta Descartes je dualizmu dao vrlo snažnu ideologijsku ukorijenjenost. Za Descartesa duša, odvojena od tijela, nije više princip života, nego postaje predmet samoj sebi. Upravo ovdje započinje Jonasov put istraživanja onog univerzalnog u živim organizmima koje se gradualno razvija, ali i kategorijalno razlikuje među mnogim oblicima bioloških manifestacija. To pak znači da Jonas započinje istraživanje forme kao principa života, odnosno započinje intenzivno s reafirmacijom aristotelizma u filozofiji biologije i samim tim u ekološkoj etici. Aristotelova formalna »podijeljenost « duše više nema isključivo tu izvornu snagu pojašnjavanja fenomena života. U bioetičkom smislu za pretpostaviti je da Jonas Aristotelovoj scalae naturae pristupa s namjerom da je učini nominalnim objašnjenjem života, ali je želi i normativno odrediti kao ukupni objekt ljudske odgovornosti, a time i inherentne vrijednosti.

Pored mnogih klasičnih shvaćanja subjektiviteta, Jonas pledira za novo utemeljenje. Krenemo li od njegova nastojanja da je biće nastajanje, a ne samo stanje, atributi koje Jonas zaziva nisu više isključivo samosvijest, samoiskustvo, identitet sa samim sobom ili kapacitet za samorefleksiju. Iskustvo, samosvijest itd. trebaju, po Jonasovu mišljenju, postati svijest cjeline i iskustvo prirode, jednako kao što je za Thomasa Sörena Hoffmana priroda »suuzrok« slobode (Hoffmann, 2013, str. 337) ili kao što je za Meyer-Abicha čovjekovo postojanje i tjelesno i prirodnopovijesno, odnosno, takvo da cijela priroda $\mathrm{u}$ nama postaje čovjekom (Meyer-Abich, 1992, str. 336).

Upravo tu su-uzročnost ili postalost čovjekom Hans Jonas tematizira u bitnom dijelu svoje knjige The Phenomenon of Life pod nazivom »Is God a Mathematician?«. Jonas se pita: ako je nešto, nekakvu bit svijeta, doista moguće tumačiti kao osnovu sveg svijeta, je li tada moguće i da je »arhitekt svijeta« ujedno i proizvođač amebe, odnosno jednog izrazito jednostavnog biološkog organizma? Grčko »matematiziranje « i novovjekovno »geometriziranje « nije ponudilo rješenje za biološko objašnjenje kretanja, kako u kvantitativnom, tako ni u kvalitativnom smislu. Zato je, kaže Jonas, potrebna duša (soul; forma) kao princip ili uzrok kontinuiranog spontanog i racionalnog kretanja, odnosno potreban je princip koji ima dvojaku manifestaciju i može biti uzet kao univerzalni fizički princip (Jonas, 1966, str. 70). 
Prirodna selekcija zamjenjuje teleologiju, ali ostavlja dva pitanja neodgovorenima: 1) kako nastaje život, kako započinje cijeli proces evolucije, abiogeneza ili Aristotelova spontana generacija; 2) kako to da jednostavniji organizmi teže složenijim organizacijama i svojstvima.

Za Jonasa težnja organizama - težnja koja dolazi iz njih samih - s velikom vjerojatnošću upućuje na svrhovitost, na imanentnu težnju k cilju. Svijest proizlazi iz materije i prirode. Ona nije duša, kako je tumači Descartes, isključivo čovječje ekskluzivno vlasništvo, ona je u prirodi. Po Jonasovu filozofijskom shvaćanju biologije, duša ponovno postaje princip tijela, a što upućuje na formu kod Aristotela. Dakle, svijest se ne tumači ni emergentno ni epifenomenalno, nego kao zametak u samoj formi specifičnog tijela čija se potpuna realizacija nalazi u potencijalnosti.

U početnom detektiranju in-formiranosti tijela, Jonas ekskurs o dokazivanju slobode započinje temom metabolizma. U metaboličkom prisvojenju drugog, potrebi da se uđe u odnos s prirodom, tj. okolišem kako bi se održala samosvojnost, Jonas vidi naznake ne samo fenomenološkog sebstva nego i prirodnog - od prirode neodvojivog - postojanja u svijetu. Potrebom da se tvar iz prirode (eksterijera) uzme u sebe (interiorizira) i time produži vlastita egzistencija, dokaz je postojanja individualiteta koji osjeća, promišlja i prisvaja (Morris, 2013, str. 60) naspram neke drugotnosti, a sve to znak je stanovitog »samo-centriranog individualiteta, koji stoji sam za sebe naspram ostatka svijeta, praveći suštinsku granicu između onog 'unutrašnjeg' i onog 'izvanjskog' " (Jonas, 1966, str. 79).

Upućenost na izvanjsko i drugotno temeljeno je na senzitivnom i stremećem karakteru živog bića. Biće je slobodno i otvoreno naspram svijeta bez kojeg ne može jer mu, stalnom upućenošću na nutritivna dobra koja mora ekstrahirati iz prirodnog mu okoliša, izvanjsko postaje integrativno »drugo«. Nužnost takvog odnosa, koji zamagljuje slobodu, zapravo je sloboda sama koja se javlja kao mogućnost mijenjanja okoliša - čovjek u prirodu ulazi mijenjajući je zarad svojeg opstanka. U opreci i susretu s prirodom čovjek postaje slobodan da čini ono što mu osigurava opstanak. Tim otvaranjem spram svijeta čovjek se pokazuje, kaže Jonas, kao samo-transcendirajuće biće, koje u tom samo-osjećanju pokazuje sebe kao biće svijesti (Jonas, 1966, str. 83-86).

Drugi važan trenutak Jonasova teksta, po Morrisinu mišljenju, tiče se osjećaja sebstva (inwardness), aktivnog zrenja svoje esencije, mogućnosti samoshvaćanja i samosvijesti. To iskustvo i osjećaj nije, smatra Jonas, nastalo iznenada posredstvom transcendentnog faktora, nego ono svoje počelo ima u prirodi. Organizam u odnosu s izvanjskom prirodom mora biti receptivan da bi ostvario svoje potrebe. Time je u organizmu naglasak stavljen na njegovu dinamičnost, ali i princip dynamisa kako ga tumači Aristotel. Po Aristotelovu mišljenju, dynamis kao potencijalnost predstavlja kretnju prema većem stupnju savršenstva. Tako pojam postaje usko povezan s pojmom enteleheia. U probuđenosti života i njegovoj pobuđenosti za opstankom u interakciji s okolišem odražava se potencijalnost bića da bude nešto više, da dosegne svoj telos ili, kako Jonas među redcima sugerira, da dosegne zacrtani plan biološke složenosti. Samo senzitivan život može biti aktivan, smatra Jonas (1966, str. 85). U suodnosu s prirodom, formirani individualitet, čiju smo »genealogiju « spomenuli u govoru o slobodi, rafinira svoje senzacije, čime svijest o sebi te sam subjekt poprimaju distinktivnije forme.

Iako nisu svi organizmi jednake svijesti i senzacije, svi jesu postavljeni u jednu dijalektiku spram svijeta. Svi organizmi predstavljaju jedan individualitet 
koji interes svog opstanka traže putem konstruktivne povezanosti s vanjskom prirodom. Tako će i Holmes Rolston III. (2001), pišući o vrijednostima, pretpostaviti da razloge vrednovanja određenog entiteta možemo pronaći u samoj biologiji živih organizama, krećući od toga da je DNK normativni nukleus koji određuje što jest i što treba biti na određeni način u živom biću. Budući da je svaki predstavnik vrste nositelj DNK-a, tada očuvanje genskog materijala predstavlja određeni interes tog pojedinca, ali ujedno i, iako u jednom ograničenom i skromnijem obimu, svijest o svojoj vlastitoj vrijednosti koju treba očuvati. Stoga, recimo sekvoja, sa svojim genskim materijalom koji nosi nekoliko milijuna godina, ipak jest u mogućnosti vrednovati, a ne samo biti vrednovana (Rolston, 2001, str. 112-113) ili kako to Morris formulira, na svakom stupnju svijesti postoji barem rudimentarni oblik brige o sebi koji je univerzalan svim živim bićima (Morris, 2013, str. 64).

Nakon što je evoluciji pripisao brigu za biologijsko shvaćanje života, čime su biokemijski procesi jednog materijalističkog shvaćanja prirode otvorili mogućnost uvažavanju prirodnoga svijeta kao su-uzroka ljudske slobode i univerzalnog atributa živoga svijeta, Jonas mora pronaći način kako u ne-ljudskom živom svijetu pronaći pretpostavke moralnog uvažavanja. Evolucija kao opis gradualnog napretka života mora biti više od slijepog i determiniranog mehaničkog procesa. Da bi nadišao beživotni mehanicizam i pojednostavljeni materijalizam, Jonas poseže za Aristotelovim pojmom telosa. U svojem korištenju pojma Jonas nastoji izbjeći svođenje istog na genetičku usporedbu i na kozmologijsko, tj. teološko tumačenje svrhe (Morris, 2013, str. 68). Po tumačenjima nekih autora, Jonasovo teleološko shvaćanje života rezultat je znanstvene pretpostavke o isključivo eficijentnom shvaćanju prirodnih proce$\mathrm{sa}$, što Jonasu predstavlja etičku prepreku.

Svoje objašnjenje telosa Jonas iznosi u knjizi Princip odgovornost, gdje pored opisa mnogih primjera svrsishodnosti prirode tvrdi da se emergencija može shvaćati samo u jednoj aristotelovskoj ontologiji (Jonas, 1990, str. 100), dakle, ne kao odjednom iskrsavajući fenomen, nego pod spletom optimalnih okolnosti razvidnim principom. Iako se složenost i subjektivni karakter organizma ne mogu pouzdano dokazati kao rezultati inherentne svrhe, ipak, smatra Morris, Jonasovo učenje možemo uzeti kao da implicira ili barem naznačuje takav scenarij (Morris, 2013, str. 70). No mora se naglasiti da za Jonasa telos ne znači prirodni kraj, nego neprestanu težnju nekog oblika života da jednostavno bude. Tako će Jonas putem shvaćanja telosa koji Aristotel opisuje u II. knjizi Fizike doći do zaključka koji Joe Sachs opisuje na sljedeći način:

»Živa bića nemaju svrhu, oni jesu svrha.« (Sachs, 2001, str. 28; prema Morris, 2013, str. 72)

Težnja organizma za postojanjem ili održanjem u svijetu za Jonasa je glavni dokaz postojanja finalnog uzroka. To on izražava riječima kako »rađanjem života priroda objavljuje barem jednu određenu svrhu, upravo sam život - što, vjerojatno, ne znači ništa drugo do oslobođenje 'svrhe' uopće za definitivne svrhe koje se i subjektivno slijede i uživaju « (Jonas, 1990, str. 107). Zahvaljujući tumačenju svrhe u prirodi, Hansa Jonasa možemo shvaćati i u kontekstu bioetike kao svojevrsnog biocentrički orijentiranog autora (usp. Jurić, 2010). $\mathrm{Na}$ tragu bioetičkih implikacija specifičnog viđenja telosa u prirodi kao neprestane realizacije vlastitog postojanja, a time i interesa, Jonasova se filozofija podudara s konceptom filozofa Paula Taylora. Sva živa bića imaju interesno dobro jer su, po Taylorovu mišljenju, »teleološki centri života«, a što im garantira moralno uvažavanje. Slično kao Aristotel, Taylor smatra da svako 
živo biće posjeduje specifičnu prirodu koja određuje i specifično dobro te vrste, ali to dobro ne predstavlja - kao kod Aristotela - suštinu ili dušu, nego jedan od vidova prirode. To što živa bića jesu na određen način, ne znači da im je zagarantirano moralno uvažavanje te da smo moralno odgovorni prema njima. Normativnost glede prirode Taylor temelji na pravilima i dužnostima koji proizlaze iz »poštovanja prema prirodi« i na prioritetnim pravilima koja proizlaze iz sukoba između moralnih zahtjeva ljudi i zahtjeva životinja. Taj drugi kriterij predstavlja skup podkriterija koji se uspostavljaju i poštuju u ovisnosti o situaciji, a da se pri tome ne favorizira ni ljudski ni ne-ljudski subjekt (de Žarden [des Jardin], 2006, str. 217-221).

\section{Zaključak}

Aristotel je svijet prirode objašnjavao inzistirajući na metafizičkom osloncu koji će podupirati empirijsku građu. Kretanje, koje je kod Aristotela određeno temeljnim pojmovima entelecheia, dynamis i telos predstavljalo je za neke autore metafizički balast koji teze izlučene iz empirijskih istraživanja stavlja u rang filozofske fikcije. Međutim, kako pokazuju Fran O'Rourke i Theodore Scaltsas, metafizika, barem u jednom slabijem vidu, daje obećavajuću snagu argumentima koji se mogu iskoristiti u ekoetičkim i eko-filozofskim problemima. Problem odnosa cjeline i individue te njihovo moralno vrednovanje mogu se pokušati tumačiti lučeći uvide iz Aristotelovih eksplikacija odnosa akta i potencije. Ono što pojedine supstancije jesu u aktu njihova je realizirana individualna forma, ali ono opće ujedno je i bit svih jedinki koje dijele slične ili iste karakteristike. Stoga je ta bit ujedno i ono što »tek treba biti« jedne konkretne jedinke, kao i neke buduće jedinke koja će konkretizirati svoje postojanje unutar neke grupe i koja će u sebi realizirati svojstva općeg putem tog općeg, koje u njoj obitava u modalitetu potencije. Cjelina će se tako moći tumačiti i znanstveno-taksonomijski i metafizičko-formalistički. Aristotelova »ekoetika« tako iz perspektive ne gubi ni individualnu biološku supstancu (biljka, životinja, čovjek), ni opću dimenziju (vrsta, ekosustav).

Ono što bismo mogli zaključiti iz Jonasova nastojanja jest da on pokušava afirmirati filozofiju biologije kroz afirmaciju života. Jonas je uvidio značaj Aristotela za tumačenje biologijskih fenomena te se u jednoj adaptiranoj aristotelovskoj ontologiji krio, po Jonasovu mišljenju, potencijal za tumačenje prirode kao potencije, ali ne tek pukog života, nego eudaimonijskog, smislenog i smislu podatnog življenja. Êthos tada nije više puki okoliš ili okruženje, ono je integral ljudskoga postojanja jer su-uzrokuje samog čovjeka. Eidos koji je prozret u materiji aktivni je faktor kretanja u smislu evolutivnog usložnjavanja, a kretanje kao telos i entelecheia čine, kako je već rekao Jonas, kulminaciju života. Međutim, kulminacija života ne podrazumijeva samo samoostvarenje čovjeka nego i, kako navodi Nussbaum (2006), ostvarivanje potencije svake jedinke čija je putanja ostvarenja zacrtana u njegovom telosu.

Taj opstanak života u svijetu praćen je mnogim oblicima i zahtijeva neraskidivu interakciju i međuodnos te je svaki živi organizam neminovno u svom opstanku usmjeren na izvanjsko i drugo. Čovjek spram ne-ljudske prirode stoji u specifičnom moralnom odnosu, što motivira Jonasa da kroz svoju filozofiju života stvori pretpostavke za etiku odgovornosti. Znači, ukoliko je Aristotel sve podređivao životu u zajednici, utoliko Jonas sve podređuje životu. Time je njegova zajednica proširena vizura odgovornosti na cjelokupnu prirodu. U tom se smislu treba sagledati apel Vittorija Höslea za metafizičkom domovi- 
nom tehničke civilizacije (Hösle, 1996, str. 12). Čovjek introspektivno može spoznati svoju svrhovitost (Vogelsang, 2003, str. 1067), ali i svrhovitost - ako uoči važnost evolucijskog tumačenja - cjelokupnog biološkog svijeta.

U jednom osebujnom holističkom pogledu na svijet, Aristotel i Jonas predstavljaju sintetičku snagu filozofske misli koja teži naglasiti dinamički princip kao princip neprestano mogućeg i na budućnost usmjerenog kretanja, čime se njihova filozofija može smatrati filozofijom, ne optimizma, već optimuma. Taj se optimum ogleda u stanju svijeta i prirode u kojemu život ostvaruje najbolje svoje mogućnosti. Svijet u kojemu kontinuum života predstavlja vrijedan dokaz specifične mogućnosti physisa te pruža garancije da osjećaj odgovornosti koji iz njega proizlazi sam u sebi nosi predmet obveze.

Dakle, physis kao forma, koju Jonas preuzima od Aristotela, predstavlja okosnicu za tumačenje prirodnoga svijeta u kojemu ni jedan od dva aspekta stvarnosti nije onaj dominantni. Priroda nije ni sluškinja, ni disponirani eksperimentatorski prostor - kako to ona biva u okviru scijentističkog redukcionizma - nego putem forme i njenih specifičnih kretanja ona postaje skrovište života koji se treba čuvati. U današnjim znanstvenim stremljenjima Jonasovo nastojanje predstavlja potrebu za metafizičkom uokvirenošću kao jednom normativnom paradigmom. Taj je okvir vapijuća samorestrikcija koja stoji pred znanošću kao neprestanom otvorenošću i nepreglednom mogućnošću tehničke opstojnosti. Time, kako tvrdi Hull (2000), metafizička koncepcija stoji kao potreba, ali ne da bi se stvari učinilo dogmatskim, nego da bi se učinilo da stvarnost jednostavno bude.

\section{Literatura}

Anders, Svein; Lie, Noer (2016). Philosophy of Nature. Rethinking Naturalness. New York: Routledge.

Aristotel. (1985). Metafizika. Prev. Tomislav Ladan. Zagreb: Sveučilišna naklada Liber.

Aristoteles [Aristotel] (2011a). O rađanju životinja. Prev. Slobodan Blagojević. Beograd: Paideia.

Aristoteles [Aristotel] (2011b). O delovima životinja. Prev. Slobodan Blagojević. Paideia: Beograd.

Brune, Jens Peter (2003). »Razumijevanje živoga? Aktualnost Jonasove filozofije organskog«. Prev. Tihomir Engler. Filozofska istraživanja 23 (2003) 4. Str. 1039-1059.

Barnes, Jonathan (1996). Aristotel. Prev. Filip Grgić. Zagreb: KruZak.

Boylan, Michael (2017). »Aristotle: Biology«. Internet Encyclopedia of Philosophy. Dostupno na: https://iep.utm.edu/aris-bio/ (pristupljeno 10. 1. 2021.).

de Žarden, Džozef R. [des Jardin, Joseph R.] (2006). Ekološka etika. Uvod u ekološku filozofiju. Prev. Aleksandar Dobrijević. Beograd: Službeni glasnik.

Guthrie, Wilhelm Kieth Chambers (2007). Povijest grčke filozofije. Knj. 6: Aristotel: sučeljavanje. Prev. Luka Boršić. Zagreb: Naklada Jurčić.

Hösle, Vittorio (1996). Filozofija ekološke krize. Moskovska predavanja. Prev. Darija Domić. Zagreb: Matica hrvatska.

Hull, David L. (2000). »The Metaphisics of Evolution«. U: Keller, David R.; Golley, Frank B. (ur.), The Philosophy of Ecology: From Science to Synthesis. Athens (GA): University of Georgia Press. Str. 247-263.

Jonas, Hans (1966). The Phenomenon of Life. Towards a Philosophical Biology. New York: A Delta Book. 
Jonas, Hans (1990). Princip odgovornost. Pokušaj jedne etike za tehnološku civilizaciju. Prev. Slobodan Novakov. Sarajevo: Veselin Masleša.

Jurić, Hrvoje (2010). Etika odgovornosti Hansa Jonasa. Zagreb: Pergamena.

Hoffmann, Thomas Sören (2013). »Bioetika i mnogostrukost pojmova prirode«. U: Krznar, Tomislav, Čovjek i priroda. Prolog određivanju odnosa. Zagreb: Pergamena. Str. 329-338.

Lennox, John (2017). »Aristotle's Biology«. U: The Stanford Encyclopedia of Philosophy. Dostupno na: https://plato.stanford.edu/archives/spr2017/entries/aristotle-biology/ (pristupljeno 10. 1.2021.).

Leopold, Aldo (1966). A Sand County Almanac. New York: Ballantine Books.

Marietta, Don E. (1998). »Environmental Holism and the Individual«. U: Botzler, Richard G.; Armstrong, Susan J. (ur.), Environmental Ethics: Divergence and Convergence. Boston: McGraw-Hill. Str. 454-466.

Mayr, Ernst (1998). To je biologija: Znanost o živome svijetu. prev. Josip Balabanić. Zagreb: Dom i svijet.

Mayr, Ernst (2000). Darwinov veliki dokaz: Charles Darwin i postanak moderne evolucijske misli. prev. Josip Balabanić. Zagreb: Dom i svijet.

Meyer-Abich, Klaus Michael (1992). »Samovrijednost prirodnog susvijeta i zajednica prava prirode«. Socijalna ekologija 1 (1992) 3. Str. 335-345.

Mono, Ž. [Monod, J.] (1983). Slučajnost i nužnost: ogled o prirodnoj filozofiji moderne biologije. Beograd: Rad.

Morris, Theresa (2015). Hans Jonas's Ethic of Responsibility. From Ontology to Ecology. New York: State University of New York Press.

Nussbaum, Martha (2006). Frontiers of Justice. Cambridge (MA): Harvard University Press.

O'Rourke, F. (2004). »Aristotle and the Metaphyics of Evolution«. The Review of Metaphysics 58 (2004) 1. Str. 3-59.

Rolston, Holmes, III (2001). »Naturalizing Values«. U: Pojman, Louis P.; Pojman, Paul; McShane, Katie (ur.). Environmental Ethics: Readings in Theory and Application. Belemont: Wadsworth. Str. 105-119.

Scaltsas, Theodore (1994). »Substantial Holism«. U: Scaltsas, Theodore; Charles, David; Gill, Mary Louise (ur.), Unity, Identity, and Explanation in Aristotle's Metaphysics. New York: Clarendon Press. Str. 107-128.

Škorić, Marko; Kišjuhas, Aleksej (2012). Evolucija i prirodna selekcija: od Anaksimandra do Darvina. Beograd: Mediterran publishing.

Vogelsang, Frank (2003). »Ljudski bitak kao izvor trebanja: o postavci teleološke ontologije kod Hansa Jonasa«. Prev. Svjetlana Lončarić. Filozofska istraživanja 23 (2003) 4. Str. 1059-1077. 
Saša Marinović

\title{
Teleology and Evolution - Aristotle and Hans Jonas in the Context of Environmental Ethics
}

\begin{abstract}
Aristotle has interpreted research done by empirical methods using metaphysical concepts extensively. According to some authors, his metaphysically intoned philosophy of biology is compatible with the modern theory of evolution and with some of the essential topics of ecological ethics. We will try to show how the interpretation of the substantial whole, under the aspect of the notion of potentiality, is Aristotle's contribution to the debates of eco-ethical holism. Furthermore, we will show how Hans Jonas also finds the possibility of valuing the individual organic substance in Aristotle's works, which are not only representatives of the human species. Hans Jonas pleads for a revision of the modern theory of evolution, which, combined with some of Aristotle's metaphysical elements, could avoid the reductionism to which it was exposed after Descartes.
\end{abstract}

\section{Keywords}

Aristotle, evolution, substantial whole, Hans Jonas, ethics of responsibility, environmental ethics 